\title{
Combat New Normal Life and Remote Emergency Learning During Pandemic Crisis: A Perspective from Public Universities Students
}

\author{
Md. Zia Uddin \\ Assistant Professor, Department of Public Administration, Comilla University, Bangladesh
}

\begin{abstract}
The Bangladeshi education system has resorted to a virtual emergency mode of learning in order to sustain teaching and learning practices in educational institutions, providing a quick fix to the challenges. From the perspective of public university students, the researcher employed a qualitative study approach to investigate the impact of the COVID-19 outbreak on tertiary education in Bangladesh. The primary data was collected via a well-designed online questionnaire, which was completed by 150 persons. Public universities in Bangladesh use virtual platforms to deliver online classes. University facilities and infrastructure, a robust national data infrastructure, appropriate computer devices, and excellent and affordable data services for students are all required for online instruction. The goal of the study is to determine the practicality and applicability of online education, as well as how students deal with the risk of Covid-19. This research identified a number of unanticipated disruptions in students' learning, as well as a drop in excitement and study hours, difficulty with student-teacher interactions, and a variety of physical, emotional, and financial issues associated to academic studies. According to the research, the most typically mentioned issues by students include network and facilityrelated hurdles, as well as personal and socio-psychological challenges. A lack of technological infrastructure, a high cost of internet, a slow internet connection, a family's financial difficulty, and student mental strain were also recognized as important impediments to online education by the majority of students. The study presented several recommendations to policymakers based on the findings to help them overcome the challenges of online classrooms in the future.
\end{abstract}

Keywords: Emergency virtual learning, online class, network, psychological stress, academic fear, Covid-19, Tertiary level.

DOI: $10.7176 / \mathrm{JEP} / 12-24-10$

Publication date:August $31^{\text {st }} 2021$

\section{Introduction}

In addition to the economy, the Covid-19 had a tremendous impact on educational sectors and students. To keep the illness from spreading, everyone had to maintain social distance. As a result, pupils were unable to participate in traditional face-to-face classes. Online learning was not the primary means of instruction. After the Pandemic, however, the situation shifted and education became the primary means of instruction. As a result, online platforms are used to train pupils and prolong their learning process (Mulayanti et al., 2020). Physical learning was discontinued and replaced by online teaching around the world during the Covid-19 Pandemic (Zayapragassarazan, 2020).

This Pandemic strangely revealed a fresh opportunity in Bangladesh's educational sector. Although online education was not new to Bangladesh, the pandemic situation made it possible to use it as a bridge to bridge the gap in education. After filing its first COVID-19 appeal on March 8, 2020, Bangladesh's government shut down all educational institutions on March 17, 2020 (Islam et al., 2020). The Bangladeshi government declared a "Lockdown" on March 26th to prevent the Pandemic from spreading further. Later, the ministry of education mandated that all universities continue to provide online courses. Following that, many public and private educational institutions switched to online classrooms as teaching approach. Virtual learning promotes resilient learning and provides students with valuable learning chances (Zayapragassarazan, 2020). Virtual learning gives students resources to aid in their online education (Kerres, 2020). With the outbreak of the Pandemic, new challenges arose in online education. Lack of internet access, difficulty with mobile network connections (David et al., 2020) are also noteworthy disadvantages of online education.

Bangladesh now has 46 governmental universities and 107 private institutions (UGC, 2020). The most obvious distinction between public and private universities can be seen in the sources of funding and the cost of tuition. Because public universities are funded by the government, they have cheaper instructional fees than private universities. Then, students from rural and low-income backgrounds are admitted to public universities. Students from affluent metropolitan backgrounds, on the other hand, believe private universities to be an ideal learning environment. The disparity in economic status can influence how people see online education. The researcher is based at the 29th public university. He was intrigued by students' thoughts on online teaching and learning in public universities in the context of the Pandemic. The purpose of this research is to investigate how 
people see online learning as a means of bridging the gap between school and work during the epidemic, as well as how they might improve their academic performance by using it. Furthermore, this study demonstrates the psychological, career-related frustration, and other negative repercussions that the Pandemic had on the lives of public university students. In order to gain a complete picture, the researcher plans to collect data from public university students via questionnaires.

\section{Literature Review}

The goal of this research is to find out about the advantages and disadvantages of emergency virtual classes, as well as their impact on personal and family life, physical, mental, and psychological health, and the main technical barriers to establishing online classrooms in public universities. Following the data collection and analysis, this researcher will attempt to indicate some of the expectations of public university students regarding maintaining balance in competition with their private university peers based on their responses. These findings, according to this researcher, will aid the government, policymakers, and institutional authorities in planning an academic future for universities and college students, allowing them to continue the online education process and effectively close the educational gap.

The University Grants Commission (UGC) has given its approval for colleges to use online media like Zoom and Google Meet to extend semester lectures. The Bangladesh Research and Education Network helped 147 of Bangladesh's 153 public and private universities to offer online courses (Aziz and Ahmed, 2020). Bangladesh urgently requires a well-structured and fruitful educational practice for the capacity-building of young generations in this time of crisis. It will assist them in closing the educational gap, improving their abilities and creativity, and ensuring the education sector's general growth in Bangladesh.

The vast majority of rural pupils attend government-run schools. Rural schools, on the other hand, face a major dearth of digital tools, skilled teachers, and stable system infrastructure (Rahat, 2020). These factors have stymied efforts in the country to promote online learning. Educational institutions in this country have made poor use of digital platforms for educational purposes. As a result, continuing education through this platform proved difficult. Covid-19 had numerous effects on our daily life, but the effects on education, particularly on students, are substantial obstacles to overcome. The goal of this paper is to look at the current situation of online education as well as the impact of Covid-19 on education in order for policymakers to come up with solutions to the problem now and in the future.

Online education was used to address Bangladesh's academic issue, with tertiary education serving as the foundation. Students will be able to finish their courses on time and will be able to communicate effectively with their lecturers. It also gives students the assurance they need to take online tests. However, there are certain disadvantages to taking online programs. The main drawbacks of online education are internet connection instability, high internet package prices, failure to adapt flexibility to the virtual classroom, and a lack of digital knowledge (Alam, 2020).

Students were worried about being separated from their studies, so they jumped at the chance to take online lectures (Shama and Ikbal, 2020). They do, however, lack the necessary technological instruments. Furthermore, they lack the necessary understanding to enroll in online classes. The institutions do not provide the technical means and aids to their faculty members in order to run successful online classes.

Because of the prejudice against improved family amenities, there are many unequal learning possibilities (Jager \& Blaabak, 2020). Because the majority of educational institutions already use online classes (Yen, 2020), it's critical to figure out how this method will benefit students from rural areas and those with poor socioeconomic status.

\section{Statement of the Problem}

Many academics have found it thrilling to assess online education and its impact on university students since 2020, when they began taking online classes. However, relatively few researchers concentrate on the wide topics covered by a university study. As a result, the current researcher plans to take advantage of the chance to investigate the impact of academic loss on physical, mental, psychological, economical, family, and technological factors. Through the viewpoint of public university students, the current study investigates the influence of COVID-19 on tertiary education in Bangladesh. In addition to the online class, what are students' expectations for online assessment? This subject will also be looked at so that a portfolio of student proposals may be presented to the university's administrative policymakers.

\section{Methodology}

\subsection{Target Group}

The information is gathered solely from primary sources. Convenient sampling was used to select 150 university students for the study in order to acquire enough data to answer the research topics. They were students from seven public universities in each of the cities of Dhaka, Cumilla, and Chittagong. There were 90 female students 
and 60 male students among them. Their ages ranged from 20 to 27 , with a mean of 21 . In terms of academic year, the majority of students were undergraduates, with only $10 \%$ being graduate students. The students were from a variety of disciplines, including Public Administration, English, Economics, Civil Engineering, Law, Physics, CSE, and Bangla.

\subsection{Instruments Used in Data Collection}

Data was collected between the 15th of June and the 15th of July, 2021. During the COVID-19 epidemic, a Google Form was utilized to collect input from students at several public universities about their decision to implement an emergency virtual learning and online assessment strategy. The data was designed and collected using snowball sampling procedures. After collecting the data, cross tabulation and Google form responses summary software were used for data analysis. The findings of the study were presented in statistical tables.

\subsection{Data analysis methods}

A questionnaire was administered to the students that collected primary data on several aspects that are directly related with Virtual distance learning such as prior experience of virtual class, technical expertise, type of gadgets and internet connection used, internet speed, duration of class, psychological health issue, family crisis and its impact on mental stress level, attractiveness of the course contents, and barriers of online class etc. The researcher collected data from Google forms that was divided into five sections and obtained percentages from the summary of the Google form. There are a few open-ended questions to elicit some solid realistic answers and recommendations to address the gap in online classes. Unlike previous studies that focused solely on students' perceptions, this study investigates students' mental and psychological health issues or stress, as well as careeroriented fear, during this pandemic period.

Based on the information of Open-ended question, a conclusion will be drawn as to whether it is appropriate to use online assessment methods in the midst of the Corona virus outbreak without taking into account the necessary infrastructure in public universities, where the majority of students come from lower socioeconomic backgrounds.

\subsection{Limitations}

Every study, including this one, has limitations. The main limitation of this study is that more participants could not be arranged for the interview session due to the pandemic.

\section{Data Analysis and Discussion}

5.1 Demographic Survey

This section primarily focused on the frequency distribution of public university students' views on online classes in the context of the COVID-19 epidemic and its impact on their physical, mental, psychological, and financial well-being. Here, opinions on different aspects were collected to assess the students' intention, which helped the researcher conclude whether it is logical or the infrastructures are well-equipped for online classes. 

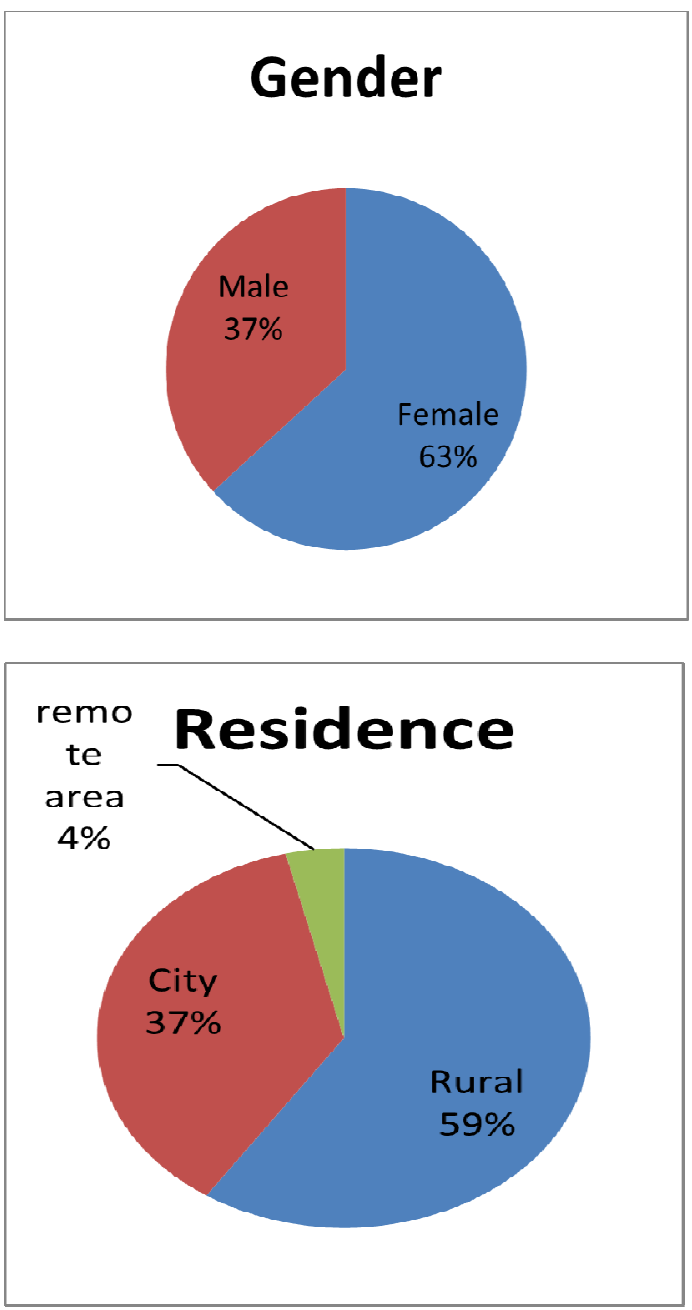

Figure 1: Demographic Variation

Analysis has been made based on the frequency distribution of the opinion of the respondents. From pie 1, it has been seen that among the participants there were $63 \%$ female and $37 \%$ male respondents. From pie 2 , the researcher has received data from 20-24 years age participants in their second year to the fourth year of Undergraduate degree at university. Only $4 \%$ of participants were found responding from the remote area as their residence; on the contrary, 37\% were from city life, and most (59\%) of the participants were from rural areas (pie 3). To continue further survey regarding virtual distance learning, have computer knowledge is a Must. However, as a matter of sorrow, the researcher has discovered that $67 \%$ (pie 4) of the participants did not know or train on computers. From this viewpoint, the implementation of virtual classes might be regarded as stress for students who do not have computer training and live in remote areas.

\subsection{Available Infrastructure to Run Study}

Before beginning to construct an online learning system, in part or in its whole, it is critical to assess the needs of the intended learners, the curriculum to be given, and the project's context. Any infrastructure, once built, must be able to evolve to meet changing student needs, technology, and curricula. Due to the Covid-19 epidemic, most educational establishments are offering classes online, making it impossible for students in outlying locations and communities to attend classes. Electricity is not the only issue in Dhaka, Cumilla, and Chittagong. The mobile phone network in those areas is also terrible. The network and deficiency of separate reading rooms or course materials are also considered to study the real scenario behind the implementation of online classes at the Tertiary level.

The response of participants to the availability or access to infrastructure to the preparedness for virtual distance classes is shown in the table below (Table 1). The chart shows that the majority of students have their own personal place where they can attend online classes without being disturbed. While 2.8 percent of participants from lower-middle-class backgrounds have a private reading room at home, they must share it with their siblings; 44.3 percent do not have a personal reading room, limiting their study frequency and total attendance. The majority of participants $(80 \%)$ use android phones to access the internet, while $20 \%$ of students 
do not have android phones and hence are unable to participate in online classes. Only $36.8 \%$ of city dwellers utilize Wi-Fi for internet access, while the majority of students, around 60.4 percent, use mobile data for internet access since it is more convenient for students of all socioeconomic backgrounds. Due to the fact that few students originate from low socioeconomic backgrounds, the poll found that 1.9 percent of students could not afford any type of internet connection. The majority of participants $(80 \%)$ have Android phones as their devices to afford costly emergency virtual classes and stay in touch with study while 6.3 percent of participants couldn't afford an Android phone to keep up with their classmates in the race. Most students utilize mobile data for their classes, and it's inevitable that they'll run against network issues in rural or isolated places. Furthermore, during the COVID-19 situation, more than half of the participants use the android phone for academic studies, and only $12 \%$ utilize it for both academic and leisure objectives. This researcher discovered that 59.4 percent of participants use the internet on a regular basis without any particular reason when conducting a poll on the topic. The exception discovered that a small percentage of participants, roughly 0.9 percent, do not use the internet like their classmates because they cannot afford a digital device. When taking online classes or participating in presentations, 60.4 percent of participants from rural or distant places strongly indicate that they constantly have poor network problems. Participants from the city indicate that $17 \%$ of them have experienced poor network problems on occasion, whereas 22.6 percent have never experienced poor network problems. Students in online classes, like those in traditional face-to-face classes, must have access to teaching tools. Despite this, 47.2 percent of participants expressed disappointment that e-resources were not provided to them before each lesson; just 26.4 percent assured that they received e-resources before each class.

Table 1: Visual Distance Learning's Infrastructure

\begin{tabular}{|c|c|c|c|c|c|c|}
\hline Variables & \multicolumn{6}{|c|}{ Percentages } \\
\hline $\begin{array}{l}\text { Each student has their } \\
\text { own Android phone: }\end{array}$ & \multicolumn{3}{|c|}{ a) ) $80 \%$ (Yes) } & \multicolumn{3}{|c|}{ b) $20 \%(\mathrm{No})$} \\
\hline $\begin{array}{l}\text { At home, students have } \\
\text { their own reading room: }\end{array}$ & $\begin{array}{l}\text { a) } 52.8 \% \\
\text { (Yes) }\end{array}$ & \multicolumn{2}{|l|}{$\begin{array}{l}\text { b) } 44.3 \% \\
\text { (No) }\end{array}$} & \multicolumn{3}{|c|}{$\begin{array}{l}\text { c) } 2.8 \% \\
\text { (Doubling with siblings) }\end{array}$} \\
\hline $\begin{array}{l}\text { Access to e-resources } \\
\text { prior to class: }\end{array}$ & $\begin{array}{l}26.4 \% \\
\text { Always }\end{array}$ & \multicolumn{2}{|l|}{$\begin{array}{l}47.2 \% \\
\text { Never }\end{array}$} & \multicolumn{3}{|l|}{$\begin{array}{l}26.4 \% \\
\text { Sometimes }\end{array}$} \\
\hline Usage of Mobile Phone : & $\begin{array}{l}65 \% \\
\text { Academic }\end{array}$ & \multicolumn{2}{|c|}{$23 \%$ Entertainment } & \multicolumn{3}{|l|}{$\begin{array}{l}12 \% \\
\text { Both }\end{array}$} \\
\hline $\begin{array}{l}\text { In residential areas, } \\
\text { students encounter an } \\
\text { inadequate network }\end{array}$ & $\begin{array}{l}60.4 \% \\
\text { Always }\end{array}$ & \multicolumn{2}{|l|}{$\begin{array}{l}22.6 \% \\
\text { never }\end{array}$} & \multicolumn{3}{|l|}{$\begin{array}{l}17 \% \\
\text { Sometimes }\end{array}$} \\
\hline $\begin{array}{l}\text { Internet connection types } \\
\text { at home: }\end{array}$ & $\begin{array}{l}60.4 \% \\
\text { Mobile } \\
\text { Data }\end{array}$ & $\begin{array}{l}36.8 \% \\
\text { Wi-Fi }\end{array}$ & \multicolumn{2}{|c|}{$\begin{array}{l}0.9 \% \\
\text { Broadband connection }\end{array}$} & & $\begin{array}{l}1.9 \% \text { Could not } \\
\text { afford }\end{array}$ \\
\hline $\begin{array}{l}\text { Gadgets for Online } \\
\text { Classes at an Affordable } \\
\text { Price: }\end{array}$ & $\begin{array}{l}\text { a) } 2.8 \% \\
\text { Personal } \\
\text { desktop }\end{array}$ & $\begin{array}{l}\text { b) } 10 \% \\
\text { Laptop }\end{array}$ & $\begin{array}{l}\text { c) } 0.9 \% \\
\text { Ipad/Tab }\end{array}$ & \multicolumn{2}{|c|}{$\begin{array}{l}\text { d) } 80 \% \\
\text { Smart phone }\end{array}$} & $\begin{array}{l}\text { e) } 6.3 \% \\
\text { None }\end{array}$ \\
\hline $\begin{array}{l}\text { Use of the Internet on a } \\
\text { Mobile Phone Frequency: }\end{array}$ & $\begin{array}{l}29.2 \% \\
\text { Always }\end{array}$ & $\begin{array}{l}30.2 \% \\
\text { Frequently }\end{array}$ & $\begin{array}{l}26.4 \% \\
\text { Sometimes }\end{array}$ & \multicolumn{2}{|c|}{$\begin{array}{l}13.2 \% \\
\text { Occasionally }\end{array}$} & $\begin{array}{l}0.9 \% \\
\text { never }\end{array}$ \\
\hline $\begin{array}{l}\text { Learning Preferences on } \\
\text { Social Networking Sites } \\
\text { (Multiple Response): }\end{array}$ & $\begin{array}{l}79.2 \% \\
\text { Zoom }\end{array}$ & $\begin{array}{l}28.3 \% \\
\text { Facebook } \\
\text { Messenger }\end{array}$ & $\begin{array}{l}20.8 \% \\
\text { Google } \\
\text { class }\end{array}$ & $\begin{array}{l}13.2 \% \\
\text { WhatsApp }\end{array}$ & $\begin{array}{l}41.5 \% \\
\text { YouTube }\end{array}$ & $\begin{array}{l}13.2 \% \\
10 \text { minute } \\
\text { School }\end{array}$ \\
\hline
\end{tabular}

Figure 2 shows that social media is favored by both teachers and students for implementation. There was a time when Facebook Messenger and YouTube Live were more popular than Zoom or Bdren. In the survey conducted in March 2020, 79.2 percent of participants expressed interest in the Zoom platform, while 41.5 percent expressed interest in YouTube Live. There were a surprisingly small number of people who thought WhatsApp and 10-Minute school was a good idea. 


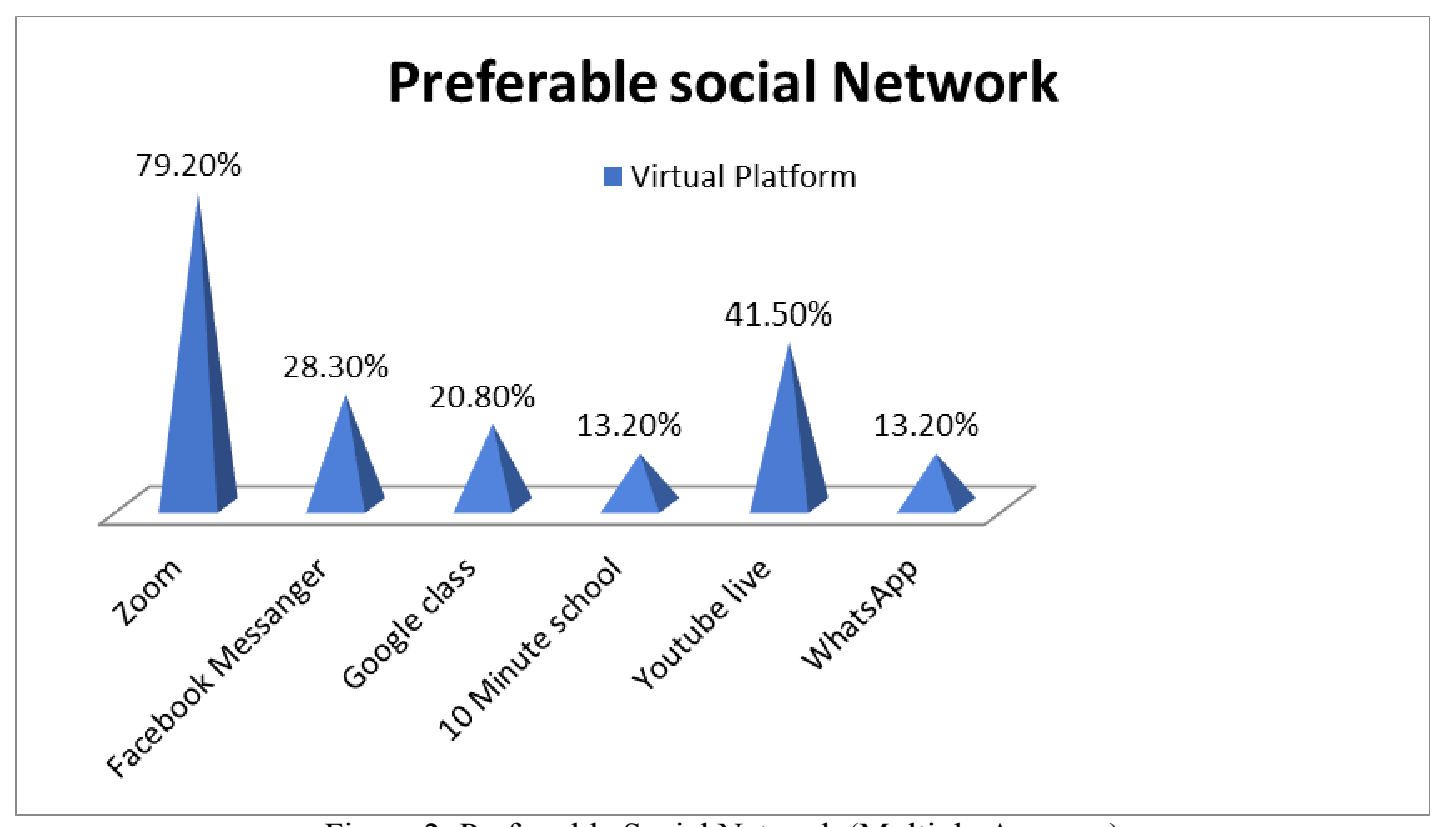

Figure 2: Preferrable Social Network (Multiple Answers)

\subsection{Public University students' experiences during Virtual distance Learning}

Since March 2020, after lockdown, the students returned home from the hall or rent house. Libraries, seminars, and residential halls were all shuttered immediately as a result of the news. Students staying in university residence halls were forced to abandon their campuses on short notice and rush back to their hometowns or villages. Their universities' academic and official activities were immediately halted. After several months, there was a declaration from UGC to continue class through the virtual platform Zoom. Almost every university started online classes in June 2020. So, the researcher intends to know students' reactions after attending online classes without exams for more than three semesters.

According to Table 2, more than half of the students firmly agreed that their internet speed during class time is less than $1 \mathrm{Mbps}$, which appears to be a hindrance to virtual learning, while only 1.9 percent of them had the benefit of having a $10 \mathrm{Mbps}$ internet connection. When asked about the regularity of their online classes, the participants became irritated. More than $38 \%$ of participants indicated that online classes were less than $50 \%$ consistent. Only 23.6 percent of participants voted on the regularity of classes with a percentage of 50 to $70 \%$. Students had earlier indicated their dissatisfaction with infrastructure in response to research question 2 . As a result, just 58 percent of them frequently attended online classes, while the rest are hesitant to attend classes on a regular basis. There were various grounds for this apprehension. During the epidemic, $21 \%$ of participants found online classes to be ineffective, $41 \%$ of participants did not have a suitable atmosphere at home in which to take online classes, and $57 \%$ of participants strongly agree and agree that there was no particular schedule time for online classes. $21.1 \%$ of participants said the lecturers' lecture quality was lower than in a typical classroom, $44.3 \%$ thought course materials in online classes were difficult to understand, and $23.6 \%$ thought the teaching materials and procedures were boring. $25.5 \%$ considered the course content to be extremely difficult to comprehend. True, online classrooms are a relatively new concept. During the epidemic, however, it offers a number of benefits. According to the survey, $69.8 \%$ agreed to attend three classes per week and $15.1 \%$ agreed to attend more than nine classes per week; $79 \%$ agreed that online classes are necessary for them; $36.8 \%$ said they spent 90 minutes per class; and $79 \%$ agreed that online classes are necessary for them. 53.8 percent agreed or strongly agreed that online education keeps pupils occupied, allowing them to avoid depression. 71.7 percent said that taking online lessons was preferable to taking no classes at all. 45 percent felt that professors' lectures were good, and $15 \%$ said they were exceptional; $49.1 \%$ said that virtual class teachers provide enough collaborative activities; Students have enough opportunities to express their thoughts in online classes, according to $57 \%$ of them.

Last but not least, despite all the advantages and disadvantages, students from all areas, whether rural or urban, were pleased with the fact that E-learning allows the instructor to record the lecture and allows learners to listen to it again, making it undeniably a beneficial way for low socio-economic students to hear the lecture without attending online classes. 
Table 2: Public university students' reaction to Virtual classes

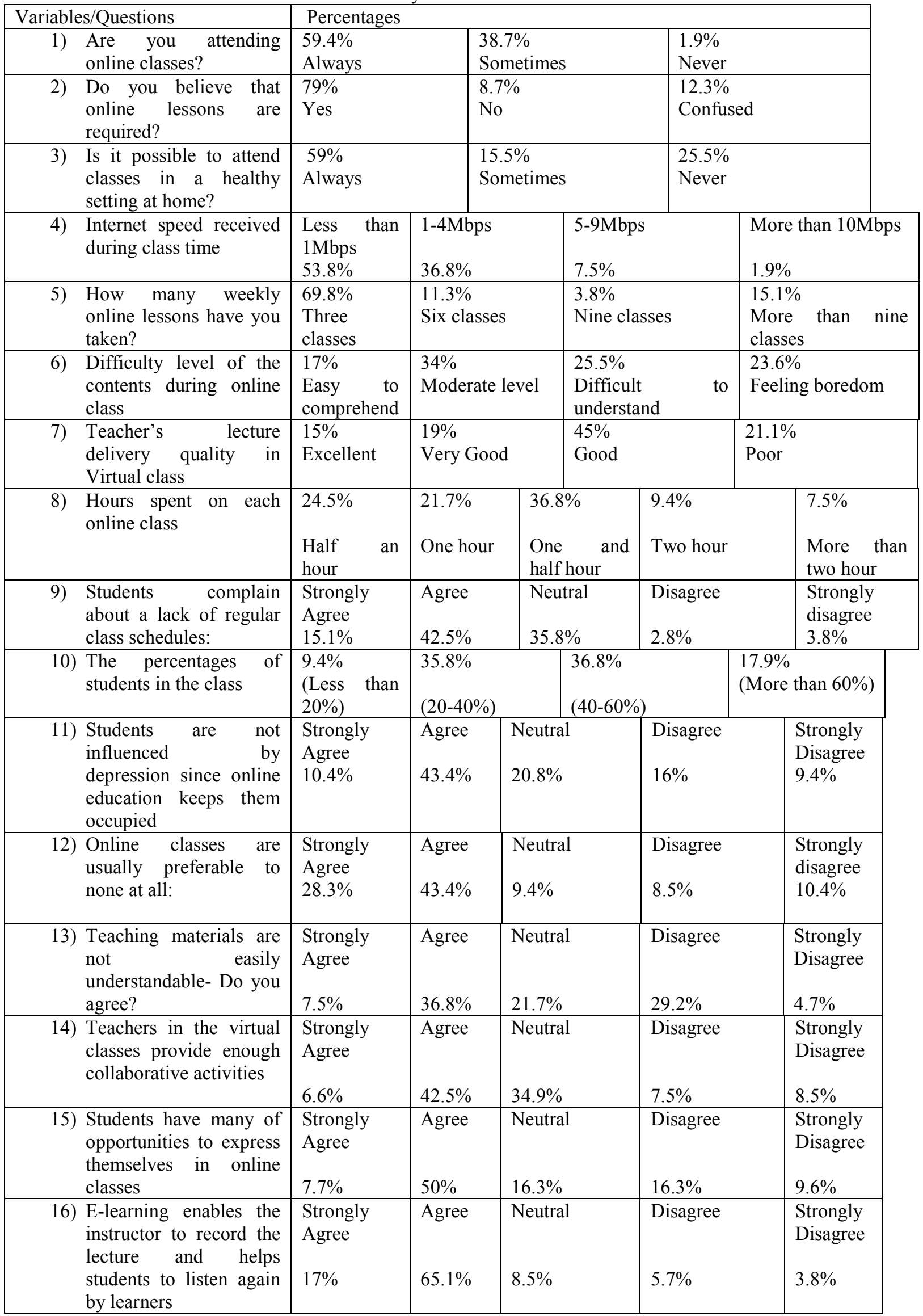




\begin{tabular}{|c|c|c|c|c|c|c|}
\hline & $\begin{array}{lr}\text { Online } & \text { learning } \\
\text { provides } & \text { two-way } \\
\text { communication } & \text { and } \\
\text { cooperation } & \text { among } \\
\text { students } & \end{array}$ & $\begin{array}{l}\text { Strongly } \\
\text { Agree } \\
52.8 \%\end{array}$ & $\begin{array}{l}\text { Agree } \\
3.8 \%\end{array}$ & $\begin{array}{l}\text { Neutral } \\
27.4 \%\end{array}$ & $\begin{array}{l}\text { Disagree } \\
10.4 \%\end{array}$ & $\begin{array}{l}\text { Strongly } \\
\text { Disagree } \\
5.7 \%\end{array}$ \\
\hline 18) & $\begin{array}{l}\text { Online learning helps to } \\
\text { enhance students } \\
\text { motivation to finish } \\
\text { studies during this } \\
\text { pandemic time: }\end{array}$ & $\begin{array}{l}\text { Strongly } \\
\text { Agree } \\
11.3 \%\end{array}$ & $\begin{array}{l}\text { Agree } \\
56.6 \%\end{array}$ & $\begin{array}{l}\text { Neutral } \\
12.3 \%\end{array}$ & $\begin{array}{l}\text { Disagree } \\
12.3 \%\end{array}$ & $\begin{array}{l}\text { Strongly } \\
\text { Disagree } \\
7.5 \%\end{array}$ \\
\hline 19) & $\begin{array}{l}\text { Online learning is an } \\
\text { excellent idea to } \\
\text { minimize the study gap } \\
\text { during covid-19 } \\
\text { pandemic time }\end{array}$ & $\begin{array}{l}\text { Strongly } \\
\text { Agree } \\
27.4 \%\end{array}$ & $\begin{array}{l}\text { Agree } \\
55.7 \%\end{array}$ & $\begin{array}{l}\text { Neutral } \\
6.6 \%\end{array}$ & $\begin{array}{l}\text { Disagree } \\
8.5 \%\end{array}$ & $\begin{array}{l}\text { Strongly } \\
\text { Disagree } \\
1.9 \%\end{array}$ \\
\hline 20) & $\begin{array}{l}\text { The use of mobile for } \\
\text { the online class is } \\
\text { flexible to learn } \\
\text { anytime, anywhere }\end{array}$ & $\begin{array}{l}\text { Strongly } \\
\text { Agree } \\
11.3 \%\end{array}$ & $\begin{array}{l}\text { Agree } \\
56.6 \%\end{array}$ & $\begin{array}{l}\text { Neutral } \\
13.2 \%\end{array}$ & $\begin{array}{l}\text { Disagree } \\
14.2 \%\end{array}$ & $\begin{array}{l}\text { Strongly } \\
\text { Disagree } \\
4.7 \%\end{array}$ \\
\hline 21) & $\begin{array}{l}\text { During online classes, } \\
\text { teachers use screen } \\
\text { share, whiteboard, slide } \\
\text { share to make the } \\
\text { content easily } \\
\text { understood }\end{array}$ & $\begin{array}{l}\text { Strongly } \\
\text { Agree } \\
10.4 \%\end{array}$ & $\begin{array}{l}\text { Agree } \\
73.6 \%\end{array}$ & $\begin{array}{l}\text { Neutral } \\
11.3 \%\end{array}$ & $\begin{array}{l}\text { Disagree } \\
14.2 \%\end{array}$ & $\begin{array}{l}\text { Strongly } \\
\text { Disagree } \\
13.2 \%\end{array}$ \\
\hline 22) & $\begin{array}{l}\text { Have Opportunities for } \\
\text { students to interact with } \\
\text { peers during online } \\
\text { classes }\end{array}$ & $\begin{array}{l}\text { Strongly } \\
\text { Agree } \\
1.9 \%\end{array}$ & $\begin{array}{l}\text { Agree } \\
51.9 \%\end{array}$ & $\begin{array}{l}\text { Neutral } \\
27.4 \%\end{array}$ & $\begin{array}{l}\text { Disagree } \\
15.1 \%\end{array}$ & $\begin{array}{l}\text { Strongly } \\
\text { Disagree } \\
3.8 \%\end{array}$ \\
\hline 23) & $\begin{array}{l}\text { The degree to which the } \\
\text { online class is held on a } \\
\text { regular basis }(\%)\end{array}$ & $\begin{array}{l}7.5 \% \\
(0-9 \% \\
\text { regular) }\end{array}$ & $\begin{array}{l}13.2 \% \\
(10 \text { to } \\
30 \% \\
\text { regular) }\end{array}$ & $\begin{array}{l}18.9 \% \\
(30 \text { to } 50 \% \\
\text { regular) }\end{array}$ & $\begin{array}{l}23.6 \% \\
(50-70 \% \\
\text { regular) }\end{array}$ & $\begin{array}{l}36.8 \% \\
(70- \\
100 \% \\
\text { regular) }\end{array}$ \\
\hline
\end{tabular}

\subsection{Barriers of Virtual classes and Technical Issues}

Several learning interruptions were discovered among the students. In this section, from Table 3 , this researcher will shed light on the Individual and technical issues in this section. 84.9 percent of participants said they had power outages in between online classes, and 43.4 percent said they had trouble submitting assignments using the virtual learning platform. 47.2 percent strongly agreed, and 39.6 percent agreed that poor network connectivity was a major issue in online classes; 48 percent thought that classroom management by teachers was very unsatisfactory in virtual classes; and around $38.7 \%$ thought that online classrooms were not appropriate for learning. Teachers had no strong effect or motivation on $37.8 \%$ of them, 61.3 percent of them had technical difficulties with connection, and 84 percent of them mistook it for disinterest when teachers canceled classes' right before class time.

Students faced personal difficulties in addition to technical issues, such as when they were at home during lockdown. Almost $37.8 \%$ of participants think that motivation has no considerable impact on online classes, and $36 \%$ agree that students' attitudes in online classrooms have no significant impact. 84.9 percent of them also said that poor learning conditions at home are a hindrance during pandemic classes, and that participating classes online is expensive through mobile data, especially for students from low and middle socioeconomic status; more than 85 percent of the participants were suffering from mental breakdown as a result of lockdown. $64 \%$ of them suffered from real time feedback from teacher and $74.5 \%$ of them believed that Inability to focus on screen for long time is the reason behind boredom in lecture. 
Table 3: Technical and personal issues as Barriers in Emergency virtual learning

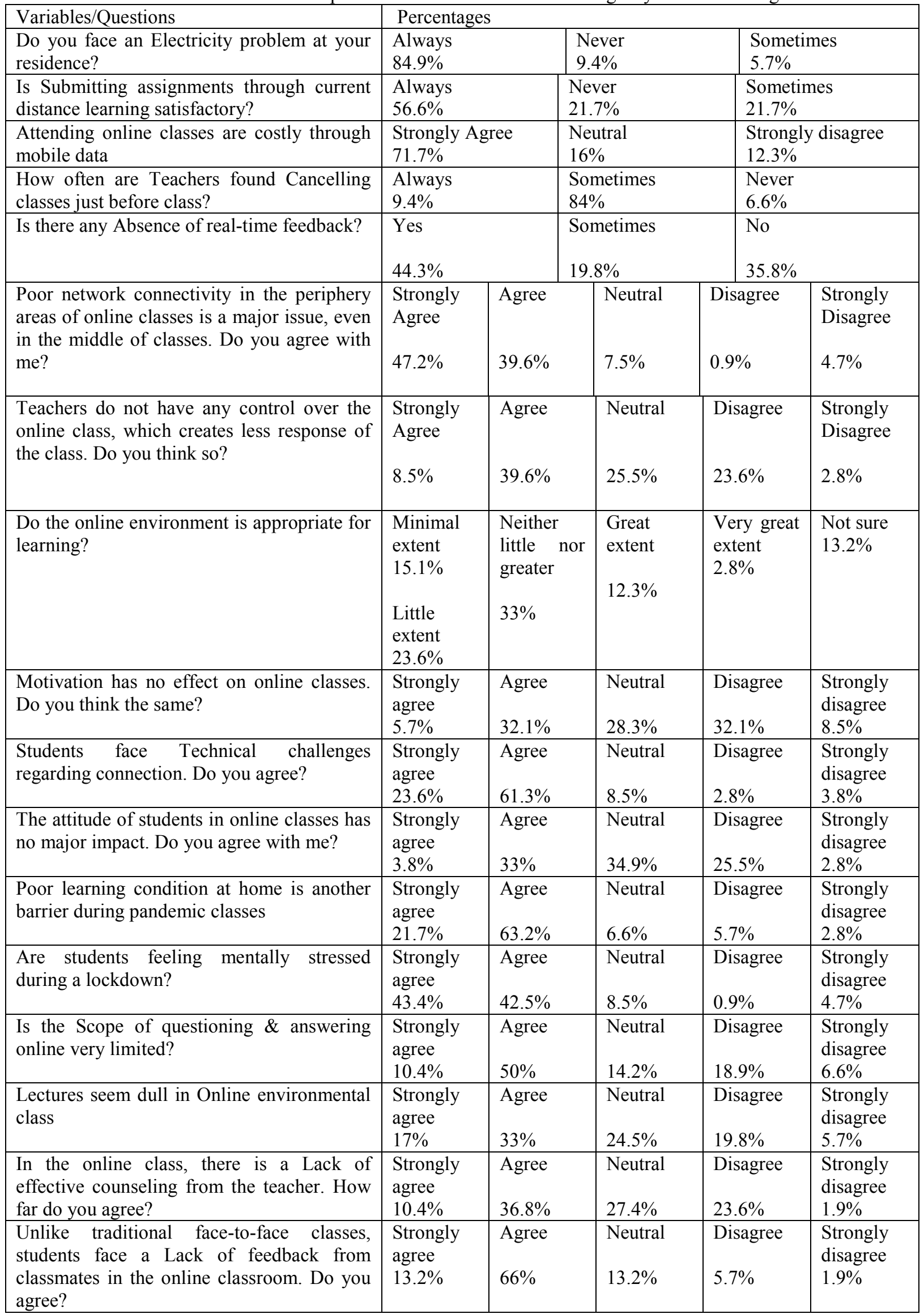




\begin{tabular}{|c|c|c|c|c|c|}
\hline $\begin{array}{l}\text { No scope of face-to-face group study with } \\
\text { friends during Pandemic situation, do you } \\
\text { think so? }\end{array}$ & $\begin{array}{l}\text { Strongly } \\
\text { agree } \\
21.7 \%\end{array}$ & $\begin{array}{l}\text { Agree } \\
58.5 \% \\
\end{array}$ & $\begin{array}{l}\text { Neutral } \\
13.2 \%\end{array}$ & $\begin{array}{l}\text { Disagree } \\
2.8 \%\end{array}$ & $\begin{array}{l}\text { Strongly } \\
\text { disagree } \\
3.8 \%\end{array}$ \\
\hline $\begin{array}{l}\text { Due to long time class students suffered } \\
\text { from an eye problem, back pain and severe } \\
\text { headache : }\end{array}$ & $\begin{array}{l}\text { Strongly } \\
\text { agree } \\
29.2 \%\end{array}$ & $\begin{array}{l}\text { Agree } \\
51.9 \% \\
\end{array}$ & $\begin{array}{l}\text { Neutral } \\
14.2 \%\end{array}$ & $\begin{array}{l}\text { Disagree } \\
3.8 \%\end{array}$ & $\begin{array}{l}\text { Strongly } \\
\text { disagree } \\
0.9 \%\end{array}$ \\
\hline $\begin{array}{l}\text { Mental health difficulties, back discomfort, } \\
\text { obesity, and headaches, among other } \\
\text { maladies, are on the rise among students and } \\
\text { instructors as a result of the lockdown. Do } \\
\text { you agree with me? }\end{array}$ & $\begin{array}{l}\text { Strongly } \\
\text { agree } \\
23.6 \%\end{array}$ & $\begin{array}{l}\text { Agree } \\
52.8 \%\end{array}$ & $\begin{array}{l}\text { Neutral } \\
16 \%\end{array}$ & $\begin{array}{l}\text { Disagree } \\
2.8 \%\end{array}$ & $\begin{array}{l}\text { Strongly } \\
\text { disagree } \\
4.7 \%\end{array}$ \\
\hline $\begin{array}{l}\text { Students get Distracted from Concentration } \\
\text { due to the Homely Environment }\end{array}$ & $\begin{array}{l}\text { Strongly } \\
\text { agree } \\
12.3 \% \\
\end{array}$ & $\begin{array}{l}\text { Agree } \\
62.3 \% \\
\end{array}$ & $\begin{array}{l}\text { Neutral } \\
16 \%\end{array}$ & $\begin{array}{l}\text { Disagree } \\
6.6 \% \\
\end{array}$ & $\begin{array}{l}\text { Strongly } \\
\text { disagree } \\
2.8 \%\end{array}$ \\
\hline $\begin{array}{l}\text { Inability to focus on the screen for a long } \\
\text { time is the reason behind boredom in } \\
\text { lectures. Do you agree? }\end{array}$ & $\begin{array}{l}\text { Strongly } \\
\text { agree } \\
13.2 \% \\
\end{array}$ & $\begin{array}{l}\text { Agree } \\
61.3 \% \\
\end{array}$ & $\begin{array}{l}\text { Neutral } \\
18.9 \%\end{array}$ & $\begin{array}{l}\text { Disagree } \\
3.8 \% \\
\end{array}$ & $\begin{array}{l}\text { Strongly } \\
\text { disagree } \\
2.8 \%\end{array}$ \\
\hline
\end{tabular}

5.5 Impact on Physical, Mental, Psychological health and Financial crisis during Pandemic online classes COVID-19 caused several modifications in the individuals' everyday habits, according to the researcher. During online classes, the financial crisis drags students into despair, dissatisfaction, and psychological stress, according to 82 percent of the participants. Almost every participant ( 73.5 percent, Table 4$)$ expressed how much they missed their university atmosphere and social connections with classmates and professors. 82 percent of them reported significant changes in their napping, dietary, and work styles. They experienced weakness, weariness, and other symptoms. Physical concerns were indicated by the majority of participants as reasons for disregarding and being uninterested in finishing their studies at home, which resulted in a detachment from their academic education and a disturbance in study flow.

The most common mental health issue identified by respondents was stress. In addition to the fear of developing COVID-19, most participants in this situation feared being confused, demotivated, and unable to adapt new academic habits, as seen in Table 4. This statement was strongly agreed with by around 83 percent of the participants. The participants were concerned about the return of classes and examinations, the publishing of results, and promotion to a new academic year ( 82 percent). They were also concerned about the post-epidemic environment, fearing that after the pandemic was under control, they would be under intense pressure to complete the course materials as rapidly as possible. As a result, it's possible that the courses' principal objectives will be missed. As they considered their future intentions, some of the participants became agitated. They were worried and unhappy about not finishing their senior year of high school on time (87 percent of the participants).

Fear of pandemic scenarios raised the stress of finding work and establishing themselves, according to 88 percent of the participants. They reasoned that the protracted school year would postpone their job search and make job competition more difficult after graduation. 87 percent of the participants were concerned about reaching the age restriction for employment in Bangladesh without being able to find work. The majority of students sobbed as they remembered how their peers from private institutions took online classes and finished their semesters so quickly. 96 percent of them agreed that postponing offline tests caused students psychological stress. These are the most important psychological stressors for students at public universities.

The financial crisis, which had an impact on their education, was mentioned by the majority of respondents (80\%). They expressed their predicament as follows: $90 \%$ of them relied on tuition or part-time job to cover their bills. All tuitions and part-time jobs were halted throughout the outbreak. COVID-19 had already had a tremendous impact on the global economy and Bangladesh's economy, therefore their family's income was drastically reduced. It was difficult for the participants $(83 \%)$ to obtain extra money to purchase internet packages because they were dependent on their family for daily needs. As a result, during a pandemic, dropout becomes a common problem. 
Table 4: Physical, Mental, Psychological and Financial Health Issue

\begin{tabular}{|c|c|c|c|c|c|}
\hline Mental/psychological/Financial & \multicolumn{5}{|l|}{ Percentages } \\
\hline $\begin{array}{l}\text { Students are experiencing a loss of } \\
\text { social interaction }\end{array}$ & $\begin{array}{l}\text { Strongly agree } \\
14.2 \%\end{array}$ & $\begin{array}{l}\text { Agree } \\
59.4 \% \\
\end{array}$ & $\begin{array}{l}\text { Neutral } \\
18.9 \% \\
\end{array}$ & $\begin{array}{l}\text { Disagree } \\
3.8 \%\end{array}$ & $\begin{array}{l}\text { Strongly } \\
\text { disagree } \\
3.8 \%\end{array}$ \\
\hline $\begin{array}{l}\text { During online classes, the financial } \\
\text { crisis is driving students into } \\
\text { despair, frustration, and } \\
\text { psychological stress: }\end{array}$ & $\begin{array}{l}\text { Strongly agree } \\
31.1 \%\end{array}$ & $\begin{array}{l}\text { Agree } \\
50.9 \%\end{array}$ & $\begin{array}{l}\text { Neutral } \\
13.2 \%\end{array}$ & $\begin{array}{l}\text { Disagree } \\
0.9 \%\end{array}$ & $\begin{array}{l}\text { Strongly } \\
\text { disagree } \\
3.8 \%\end{array}$ \\
\hline $\begin{array}{l}\text { Many students "fear academic year } \\
\text { loss owing to financial problems" } \\
\text { during the pandemic. Is it true? }\end{array}$ & $\begin{array}{l}\text { Strongly agree } \\
34 \%\end{array}$ & $\begin{array}{l}\text { Agree } \\
53.8 \% \\
\end{array}$ & $\begin{array}{l}\text { Neutral } \\
8.5 \% \\
\end{array}$ & $\begin{array}{l}\text { Disagree } \\
0.9 \% \\
\end{array}$ & $\begin{array}{l}\text { Strongly } \\
\text { disagree } \\
2.8 \%\end{array}$ \\
\hline $\begin{array}{l}\text { The sleeping, eating, and working } \\
\text { habits of students shifted } \\
\text { dramatically, resulting in weight } \\
\text { increase or obesity: }\end{array}$ & $\begin{array}{l}\text { Strongly agree } \\
30.2 \%\end{array}$ & $\begin{array}{l}\text { Agree } \\
51.9 \%\end{array}$ & $\begin{array}{l}\text { Neutral } \\
8.5 \%\end{array}$ & $\begin{array}{l}\text { Disagree } \\
2.8 \%\end{array}$ & $\begin{array}{l}\text { Strongly } \\
\text { disagree } \\
6.6 \%\end{array}$ \\
\hline $\begin{array}{l}\text { Students are concerned about the } \\
\text { resumption of classes and the next } \\
\text { examination period: }\end{array}$ & $\begin{array}{l}\text { Strongly agree } \\
34 \%\end{array}$ & $\begin{array}{l}\text { Agree } \\
47.2 \% \\
\end{array}$ & $\begin{array}{l}\text { Neutral } \\
14.2 \% \\
\end{array}$ & $\begin{array}{l}\text { Disagree } \\
1.9 \%\end{array}$ & $\begin{array}{l}\text { Strongly } \\
\text { disagree } \\
2.8 \%\end{array}$ \\
\hline $\begin{array}{l}\text { Students experience worry and } \\
\text { sadness as a result of not being able } \\
\text { to finish their final year of school on } \\
\text { time }\end{array}$ & $\begin{array}{l}\text { Strongly agree } \\
48.1 \%\end{array}$ & $\begin{array}{l}\text { Agree } \\
39.6 \%\end{array}$ & $\begin{array}{l}\text { Neutral } \\
6.6 \%\end{array}$ & $\begin{array}{l}\text { Disagree } \\
0 \%\end{array}$ & $\begin{array}{l}\text { Strongly } \\
\text { disagree } \\
5.7 \%\end{array}$ \\
\hline $\begin{array}{l}\text { The pandemic crisis exacerbated } \\
\text { students' anxiety about finding work } \\
\text { and establishing themselves }\end{array}$ & $\begin{array}{l}\text { Strongly agree } \\
44.6 \%\end{array}$ & $\begin{array}{l}\text { Agree } \\
44 \% \\
\end{array}$ & $\begin{array}{l}\text { Neutral } \\
3.8 \% \\
\end{array}$ & $\begin{array}{l}\text { Disagree } \\
2.8 \%\end{array}$ & $\begin{array}{l}\text { Strongly } \\
\text { disagree } \\
4.7 \%\end{array}$ \\
\hline $\begin{array}{l}\text { Students in their final year of } \\
\text { university and those pursuing a } \\
\text { master's degree were concerned } \\
\text { about exceeding the age limit for } \\
\text { employment in Bangladesh without } \\
\text { being able to find work }\end{array}$ & $\begin{array}{l}\text { Strongly agree } \\
42.5 \%\end{array}$ & $\begin{array}{l}\text { Agree } \\
44.3 \%\end{array}$ & $\begin{array}{l}\text { Neutral } \\
8.5 \%\end{array}$ & $\begin{array}{l}\text { Disagree } \\
0.9 \%\end{array}$ & $\begin{array}{l}\text { Strongly } \\
\text { disagree } \\
3.8 \%\end{array}$ \\
\hline $\begin{array}{l}\text { During the pandemic, all tuitions } \\
\text { and part-time jobs were halted. As a } \\
\text { result, the students are experiencing } \\
\text { mental health issues. Do you agree } \\
\text { with me? }\end{array}$ & $\begin{array}{l}\text { Strongly agree } \\
45.6 \%\end{array}$ & $\begin{array}{l}\text { Agree } \\
45 \%\end{array}$ & $\begin{array}{l}\text { Neutral } \\
4.7 \%\end{array}$ & $\begin{array}{l}\text { Disagree } \\
1.9 \%\end{array}$ & $\begin{array}{l}\begin{array}{r}\text { Strongly } \\
\text { disagree }\end{array} \\
2.8 \%\end{array}$ \\
\hline $\begin{array}{l}\text { It was difficult for the participants to } \\
\text { save money for internet packages } \\
\text { because they were depending on } \\
\text { their families for daily needs, } \\
\text { especially considering the high cost } \\
\text { of online programs: }\end{array}$ & $\begin{array}{l}\text { Strongly agree } \\
48.1 \%\end{array}$ & $\begin{array}{l}\text { Agree } \\
35.8 \%\end{array}$ & $\begin{array}{l}\text { Neutral } \\
10.4 \%\end{array}$ & $\begin{array}{l}\text { Disagree } \\
0.9 \%\end{array}$ & $\begin{array}{l}\begin{array}{l}\text { Strongly } \\
\text { disagree }\end{array} \\
4.7 \%\end{array}$ \\
\hline $\begin{array}{l}\text { Private university students from } \\
\text { same session are attending online } \\
\text { exams and getting ready to apply for } \\
\text { fresh circulars. Another critical } \\
\text { aspect of psychological anguish is } \\
\text { this : }\end{array}$ & $\begin{array}{l}\text { Strongly agree } \\
38.5 \%\end{array}$ & $\begin{array}{l}\text { Agree } \\
46.2 \%\end{array}$ & $\begin{array}{l}\text { Neutral } \\
11.5 \%\end{array}$ & $\begin{array}{l}\text { Disagree } \\
1 \%\end{array}$ & $\begin{array}{l}\text { Strongly } \\
\text { disagree } \\
2.9 \%\end{array}$ \\
\hline $\begin{array}{l}\text { Students at public universities are } \\
\text { experiencing traffic congestion as } \\
\text { final examinations are postponed. } \\
\text { This causes anxiety in the mind: }\end{array}$ & $\begin{array}{l}\text { Strongly agree } \\
96.2 \%\end{array}$ & & itral & $0 \%$ & disagree \\
\hline
\end{tabular}


Apart from the risk of catching Yes

COVID-19, the majority of the participants were concerned about becoming dispersed, less motivated, and unable to adapt to new academic habits in this situation:

\begin{tabular}{l|l} 
No & May be \\
$4.7 \%$ & $12.3 \%$
\end{tabular}

\section{Recommendations}

Certain recommendations have been made based on the findings of this study that could help the important stakeholders in the country's education sector, including the government.

1. Educational institutions and the government, for example, should develop a training program on how to attend online classes and create course materials.

2. Students should be informed about the advantages of enrolling in online programs in order to avoid session jams and complete their academic cycle on time.

3. Teach students technological skills through video tutorials on how to use internet resources to improve their learning process.

4. The government and educational institutions should create or implement a specific program to help students afford gadgets like computers and smartphones through a low-interest loan or subsidy.

5. The government should pay special attention to the amount of internet data that students use.

6 . The government can set aside a particular amount of data consumption per day for students to attend online classes.

7. To avoid disconnection, true 4G internet speed must be ensured in all sections of the country.

8. Several TV and online programs on how to improve mental health during a pandemic can be broadcast. Indoor exercises, for example.

9. The government and institutions should lend a helping hand to those who are experiencing financial difficulties.

10. During the Corona Virus Crisis, educational institutions should waive a reasonable percentage of tuition fees and extend payment terms.

\section{Conclusion}

According to the data, public university students are generally prepared for online classes, assignment submission, and internet charges, yet there are certain limits in terms of attendance and collaborative work in the classroom. In the online classroom, there is a significant disparity between metropolitan and rural and distant places in terms of a range of qualities. As a result, administrators and legislators should take action after assessing students' readiness for inclusive education. In order to generalize the conclusions of this research, future studies need do more research in a range of developing countries. This research should be broadened to include more variables, and it might also involve tertiary students from Bangladesh's National universities and private universities. Despite the fact that this was a small-scale study done over a short period of time, the results indicate that students are dissatisfied with the university-subscribed services. The students, like those in other underdeveloped nations, cited limited access to computers and slow download rates as major challenges. These difficulties have an impact on how students at Bangladesh's public universities use technology. These issues, on the other hand, were mostly caused by a lack of ICT infrastructure, which could have further negative implications such as a refusal to use subscription resources on a regular basis, resulting in low satisfaction with such collections. Given the harsh reality of how online learning may be used in Bangladesh, the study has reflected this reality. The lack of a sufficient internet connection, gadgets, and the cost of mobile data, as well as the family's financial situation and the pupils' mental health, are all important hurdles in establishing online lessons for all in impoverished countries like Bangladesh. Some of the restrictions may be lifted with government and institutional assistance, allowing more students to participate in online learning. A considerable number of pupils are expected to be denied entrance to university campus due to the aforementioned constraints. The government must now pick between keeping up with the rest of the world in terms of schooling and combating the unknown COVID-19.

\section{References}

Alam, M.A. (2020), "Challenges and Possibilities of Online Education during Covid-19”, Preprints. https://doi.org/10.20944/preprints202006.0013.v1.

David, R., Pellini, A., Jordan, K. \& Phillips, T. (2020). Education during the COVID-19 Crisis Opportunities and constraints of using EdTech in low-income countries. Policy brief. https://edtechhub.org/wpcontent/uploads/2020/04/education-during-covid-19-crisis.pdf

Islam, S.M.D.U., Bodrud-Doza, M., Khan, R.M., Haque, \& M.A., Mamun, M.A. (2020). 
Exploring COVID-19 stress and its factors in Bangladesh: A perception-based study. Heliyon 6 (7), e04399. Doi: 10.1016/j.heliyon.2020.e04399

Islam, M.S., Tanvir, K.M., Amin, \& M., Salman, M. (2020, Jun 1). Online Classes for University Students in Bangladesh during the Covid-19 Pandemic- Is it Feasible? The Business Standard. https://tbsnews.net/thoughts/online-classes-universi ty-students-bangladesh-during-covid-19 pandemic-itfeasible-87454

Jæger, M. M., \& Blaabæk, E. H. (2020). Inequality in learning opportunities during Covid-19: Evidence from library takeout. Research in Social Stratification and Mobility, 68, 100524. https://doi.org/10.1016/j.rssm.2020.100524

Kerres, M. (2020). Against all odds: education in Germany coping with Covid-19. Post Digital Science and Education,2(1), 690-694. DOI: 10.1007/s42438-020-00130-7

Mulyant, B., Purnama, W., \& Pawinanto, R.E. 2020. Distance Learning in Vocational High Schools during the COVID-19 Pandemic in West Java Province, Indonesia. Indonesian Journal of Science and Technology, 5 (2), 96-107. DOI:10.17509/ijost.v5i2.24640

Rahman, M., Aziz, M.U., \& Ahmed, S.O. (2020, Aug 5). Covid-19 Boosts Digitization of Higher Education in Bangladesh. The Financial Express.https://blogs.worldbank.org/endpovertyinsouthasia/covid-19-boostsdigitization-higher-education-bangladesh

Rafe, R. (2020, Oct 22). COVID-19 deepens divide between Bangladesh's rural and Urban students. $D W$. https://www.dw.com/en/education-bangladesh/a-55358552

Shama, S., \& Ikbal, J. (2020, July 2). EDUCATION DURING A PANDEMIC: A feasibility study of online classes in Bangladesh to counteract potential study gaps caused by COVID-19 related lockdowns. https://doi.org/10.31235/osf.io/p6mws

Zayapragassarazan, Z. (2020). COVID-19: strategies for online engagement of remote Learners. F1000Research,9( 273), pp. 1-18. https://doi.org/10.7490/f1000research.1117835.1

Md. Zia Uddin is an Assistant professor of Public Administration Department at Comilla University, Bangladesh. His research interest areas are Broader Field of Governance, Administration, Management and Development; Public policy, Rural Development, Local Government, NGOs and Development, Project Management, Micro enterprise Policy and Organizational behaviour. 